\title{
THE IMPRACTICABILITY OF "ENFORCING" PEACE
}

\section{EDWIN BORCHARD†}

JusT in what réspect is the United Nations an improvement over the League of Nations? Both of them have their justification in the assurance of peace which a bewildered humanity anxiously seeks. Both of them purport to advance the cause by enforcing peace upon the socalled "aggressor." When the League sought to accomplish this aim in Manchuria (1931), in Ethiopia (1935), in German reoccupation of the Rhineland (1936), it found itself hampered by the fact that various constituent members declined to go along. But the idea that force was the "Open, Sesame" to peace was not abandoned. Finally, in 1939, after Hitler had absorbed Austria (1938) and-despite the Munich appeasement-Czechoslovakia as well (1939), while the League stood by helpless, Russia invaded Finland, and the League manifested its impotent displeasure and frustration by expelling the Soviet Government. That seems to have been the last important activity of the League.

Why it is assumed that the membership of the United States would have changed this picture is not altogether clear, unless it be thought that in the name of righteousness the United States can be induced to fight on any and all occasions. At all events, when the time came to organize a new League, because of Soviet disapproval of the old and its waning prestige, the United States took the lead in organizing it under the name of the United Nations. Its aims are the same as those of the old League, except that the Military Staff Committee (Art. 47) is to symbolize the military potency of the organization, and the acknowledged exercise of the veto power by one of the Big Five assures that nation of an immunity from the ministrations of the organization machinery.

We have seen the United Nations in action for nearly a year. Only an optimist would conclude that its deliberations on Iran and Spain constituted a contribution toward peace. Perhaps it will do better hereafter. But, as in the case of the League, it seems that the less political functions of the organization have more likelihood of accomplishment than the highly political, if not belligerent, enforcement of peace.

The proposals for enforcing the peace announced at San Francisco in 1945 are founded on the theory that peace can be "enforced" by

† Hotchkiss Professor of Law, Yale Law School; Assistant Solicitor of the Department of State, 1913-1914; U. S. Technical Adviser at the Conference on Codification of Inter* national Law, 1930; U. S. member for Committee of Experts, Inter-American Codification of International Law; contributor to legal periodicals, and author of numerous works in the fields of international law and constitutional law, etc. 
"peace-loving," "sovereign" nations on recalcitrant states, called "aggressors," in the same way that the non-conformist within a state is subjected to arrest, judicial control and punishment. The fact that states in the international constellation differ fundamentally from individuals in a municipal community, and that the method of and procedure for controlling them must of necessity be entirely different, has not been recognized by the seekers of a new world order, romantic chasers of the international rainbow.

Enforcement under the Charter rests essentially upon armed coercion by the Big Three, drawing support from the smaller member states. The theorists, in their attempt to produce the new order by coercion, are driving out of existence international law, the only law that is able to survive among a congeries of states, none of whom is entitled to pass judgment on others, and none of whom is able to enforce its judgment without inviting war. The theorists thus propose to "enforce" peace by war at a time when international relations are more irreconcilable than ever; yet they expect the promotion of law to accompany this essentially anarchistic process. This is the state of mind that the 20th century has attained. Perhaps two world wars, with their destruction of human values, were too great a shock to permit the survival of reason.

What is now happening follows from the acceptance of an assumption, made by gentlemen like Woodrow IVilson, that the world and its processes can be changed by a new charter or league. That the world's distant places are now more accessible has promoted the propaganda that an international organization is essential to the world's survival. The world has undoubtedly shrunk, but the nature of the state and the relations between states have not thereby been changed. Indeed, international propinquity has promoted nationalism and thus increased the dangers of conflict. Instead of methods to allay the growing distemper, predominant force or compulsion, a counsel of despair, is the only solution offered to us.

The Founders of this nation had before them in a much more favorable setting the problem of enforcing the Constitution upon the constituent states of this Union and firmly rejected the suggestion that force be employed on the ground that it would break up the Union and merely eventuate in war. But this fact is lost upon their successors. Madison remarked that: "The practicability of making laws, with coercive sanctions, for the States as political bodies, had been exploded on all hands." 1 Hamilton characterized the proposal as ". . . little less romantic than the monster-taming spirit, attributed to the fabu-

1. Constitutional Convention, July 14, 1787; 2 FurRrsd, TrE Recoros of IIIE FEDERAL CONVENTION OF 1787 (1937) 9. 
lous heroes and demi-gods of antiquity." 2 There is no element of the proposed theory of punishing "aggressors" which is not contested by history and disproved by experience.

Many schemes for organizing peace have dotted the centuries since the Abbe de St. Pierre announced his unworkable plan. These schemes differed from the League of Nations in that the latter was adopted by stateșmen and not in that it was any more valid. Such schemes fail because of contradictions inherent in "enforcing" peace and because they falsely assume that sovereign states can sit in judgment or agree on the meaning of such an undefinable term as "aggressor" and then carry out the judgment without upsetting the world. Nations perhaps should abandon their sovereignty, which in many respects is outdated, but no nations seem ready to do so, least of all the great powers who have sponsored the United Nations. As Elihu Root once said about a sensible solution to another problem, "they just won't do it."

Whereas international law was built on the theory of the equality of states, the new scheme involves an essential denial of this equality by making power the test of rank. Yet the maintenance of sovereignty, upon which the constituent states insist, is incompatible with regulating the conduct of states by strengthening the sinews of dictated law. On the contrary, the law that can prevail among sovereign states is not a law dictated by superior to inferior, as is the case inside a state, or in municipal law, as we call it, but only a system to which states agree, whether created by custom or by treaty among equals. The rules of neutrality, so created, but now flouted as never before, constituted a means by which society could control wars, limit their area, and restore a healthy peace. This time-tested protection of society against mutual destruction is now ostensibly abandoned, although no nation seems to have abrogated its neutrality laws, and the survivors are likely to insist upon neutrality in the civil wars that are in the offing. Whereas non-intervention was the keynote both of international law and American policy, universal intervention in other people's local affairs and in matters of which an understanding is quite wanting is now presented as the desired key to international tranquility. The idea of enforcing peace in analogy to a municipal system is only theoretically tolerable when a superstate controls all others, a condition which it is impossible to assume. There can be no superstate unless the Big Three fight it out for supremacy, and, as yet, even our wild theorists have produced no school to suggest this course. In fact, we are dealing with a congeries of sovereign states, and if the Big Three profess to be above the law, laying down the rules-most likely their whims-for states of lesser breed, long docility can hardly be assumed.

The other alternative is that sovereignty be abandoned to a federa-

2. 1 Scott (ed.), The Federalist (1894) 90. 
tion, such as the United States, with the federation having pover to enforce upon individuals the constitutional rules of the federation. Since Europe is unable to organize such a sensible organization inside a continent which should be cohesive, it is hardly to be assumed that the disparate states of the world are ready to form a federation. Only blind faith supports the belief that order can be maintained in the world by a thinly disguised military alliance of the three largest Powers. It takes such faith to believe, against history's clear warnings, that Great Britain, Russia, and the United States, facing the problems that their financial and social conditions make inexorable, are likely long to see the future in the same light. Early renewal of war is not probable; of this, exhaustion is the principal guaranty, but the growth of regionalism seems likely, with small states, while still boasting of their sovereignty, diminishing to the position of protectorates of larger units. That imperialism will suffer a serious check under this power system seems unlikely. As force grows in importance, the law recedes.

The assumption of numerous theorists that the wealness of international law is due to the lack of force behind it is responsible for much of the sorry thinking of the present day. International law is a primitive system, not because it lacks the support of force but because it deals with sovereign states who cannot be coerced by other states without entailing war. There must be a certain agreement on the law, at least among the majority. But the law gains its strength through practice, invocation by foreign offices and application by tribunals.

If such an epithet as "aggressor" under the new theory is made the test of status and action, it must be assumed that the judging nations in the Security Council-at least the large ones-will be able to agree on the meaning of such an uncertain term, not merely when applied to a particular nation, now, but also when applied to nations behaving similarly in the long future. Yet experience teaches us that agreement is exceedingly doubtful, since the judgment is reached not on impartial criteria but on subjective if political grounds, including self-interest, association, commitments, alliances, and other considerations far from legal. It is not possible to conceive that Great Britain would consider one of its dominions an "aggressor." It is not possible to imagine that Russia would find one of its satellite states to be an "aggrcssor," which presupposes Russian inability to control the recalcitrant itself. It is not possible to assume the continuance of the inter-American system if the United States should declare one of the constituent states to be an "aggressor."

Realizing the political nature of the judgment and the consequent unlikelihood of agreement, it has been suggested that the judgment as to who is an "aggressor" be left with the Court of International Justice, a body ostensibly impartial. It is blandly assumed that the Court would assume jurisdiction of such a case. Acceptance of such jurisdic- 
tion would be likely to terminate the Court's existence, since the Court depends for its existence upon the cooperation of the constituent members. Even the Customs Union case, ${ }^{3}$ which was based on Article 88 of the Treaty of St. Germain, strained the virility of the Court and did much to shake its authority in Europe.

Another weakness inherent in "enforcing" peace is revealed by recognition that "to outlaw aggression" is, by and large, an attractive formulation of "to maintain the status quo." The peace to be "enforced," under the facts of economic life, present as well as historic, must perforce be the result of war, and must immobilize geography as it emerged from war. In so far as the peace imposed upon the vanquished be not statesmanlike, i.e., conforming to the new political conditions, it must create malaise and discontent certain to break out into open dissatisfaction and conflict. The nullification of conquest as a source of title cannot be effective without the creation of a substitute method for effecting boundary and economic adjustments.

The philosophy which identifies the preservation of peace with the maintenance of the status quo and favors hounding the non-conformist has, however, disastrous consequences. A good physician attempts first to establish the nature of his patient, his constitution, his allergies, his habits, his weaknesses, and then fashions his therapeutics to harmonize with the natural tendencies of the patient. But by prescribing the use or threat of force against a nation that finds the status quo intolerable, the international physicians are abandoning diagnosis. Independent national entities do not naturally have the same political objectives, internal or external, and are likely to drift into a balance of powerwhere there is political interest-and not unity. Coercion or its threat promotes disunity. Compulsion to observe a status quo-whether called "peace" or "international law"-is a politically comprehensible device, but experience shows the device has had no success as a conciliator or pacifier. If employed against a nation in possession of arms or capable of resistance, it is likely to have unhappy results. International relations cannot be mechanized or regimented. Especially is this true if peace treaties are drawn, like many European treaties, not to reflect prevailing political trends, heal wounds and restore the lost equilibrium, but to impose unnatural conditions. In an industrial age such treaties tend to produce social diseases, peculiarly cancerous in their virulence. In the quest for peace a study of history and psychology is a more important asset than a knowledge of law or political mechanics; the emphasis on enforcement gives it a misplaced rôle in the drama.

The identification of peace with the status quo has other results. It is responsible for muddying intellectual clarity and the understanding of

3. P.C.I.J., Ser. A/B, No. 41 (Advisory Opinion, 1931). 
history. To it we owe the chameleonic epithet "aggressor," which is applied selectively to those particular disturbers of the status quo whom the dominant states happen to dislike. It is responsible for the war-spreading conception that by remaining out of wars, when the dominant states are in, the neutral is in some way guilty of immorality. Veneration of the status quo, backed by coercion, adds up to the practice of intervention, now common to many nations in spite of lip-service occasionally paid to non-intervention. It is responsible for the doctrine of non-recognition of political facts, howerer inexorable, if unwelcome to the ruling nations. It is responsible for the doctrine of sanctions, designed to bend nations to the will of the ruling group and carrying behind it a whole flood of evils. It is responsible for that rigidity and inflexibility of diplomacy, spiced by invective, which regards every proposal to alter the status quo as prima facie intolerable, though there is no exit in peaceful change. Such inflexibility is likely to be associated with self-righteousness, calculated to evole desperation and desperate men. As an incident to discountenancing neutrality-which over the centuries had demonstrated its utility-the concept of an enforced peace introduced into the language such ambiguous conceptions as "non-belligerency," which seems to justify violations of neutrality (i.e., law) while purporting to escape the risks of war and legal liability. Thus, the confusion of peace with war, which at least the traditional law had sought to distinguish clearly, is now accompanied by a whole conglomeration of ambiguities, like "international police force," "just war," "concern"- the jargon of "collective security"-which have made political life uncertain and hardly encourage hope of a profitable cooperation.

Instead of expending energy on "enforcing" peace, which is likely to fail at the first impact with reality, it seems far more practical to rescue what we can from a distracted and impoverished order by emphasizing:

1. The necessity of a workable and not too inflexible peace which will permit all peoples to resume the thread of life;

2. The necessity of putting people in all countries back to work;

3. The necessity of knitting together sundered economic (including fiscal) relations, by restoring trade with its collateral incidents and apparatus, making a beginning at meeting the problcm of unfair competition, and re-establishing gold or some substitute for gold as an automatic compensatory device for meeting the balance of payments;

4. The necessity of stimulating economic coordination in the form of commodity agreements and exchanges which would deflate the importance of boundaries, help to restore understanding, diminish unfair competition, and make possible more constructive political relations; 
5. The necessity of making the Economic and Social Council an independent corporation, like the Bretton Woods Fund and Bank, to coordinate the work of other economic and social agencies in the field of trade, production and consumption and human rights, so as to enable it to survive any disorganization of the political Security Council;

6. The necessity of curing embittered international relations by the time-honored methods of diplomacy and by affording economic opportunity, eschewing provocation, boycott, invective, and the assumed right to judge the morals of other people;

7. The necessity of foregoing the use of provocative terms which imply discrimination, such as "peace-loving" nations, "aggressor" and similar terms of self-praise or opprobrium;

8. The necessity of curtailing if not abandoning sanctions, an instrumentality of economic warfare, which widens the gap between the possessing nations and others and constitutes a constant incentive to conflict;

9. The necessity of foregoing intervention in the external and internal affairs of other nations and returning to the tried methods of nonintervention;

10. The necessity of restoring the rule of law which the modern conceit of collective security has shattered;

11. The necessity of amending the Charter in the following respects:

$a$. That it be made universal, open to all nations willing to subscribe to the Charter;

$b$. That it be deprived of its war-making threat and function and become an assembly for the consideration of mutual problems, -notably in the economic sphere, and become the agency for recommending and, if possible without force, effecting peaceful change by a two-thirds vote in the Assembly and in the Security Council;

$c$. That the status of the Assembly be changed to become a governing body of equal status with the Security Council and not merely a debating society;

$d$. That the amending process be changed so as to disable one of the Big Three or Five from frustrating amendments, which should be made by a two-thirds vote of Assembly and Council;

$e$. That no one member of the Big Five retain the opportunity to prevent the consideration of any question or any action affecting itself or another state by its negative vote;

$f$. That the profession to direct force be eliminated, since the promise of force merely begets counter-force and defeats any hope of the limitation of armaments.

The writer is under no illusions as to the feasibility of amending the Charter, since a veto from one of the Big Five suffices to prevent all 
consideration of the subject. But unless this is done, and with reasonable promptness, the members of the United Nations are not likely to remain long "united" or to achieve the professed aims of the Charter. If that should prove to be the case, the Charter will take its place with the Covenant of the League of Nations as another device marking the disappointment of man's hopes for a better regulation of his international relations. 